\title{
Seychelles: Extended Arrangement-Financing Assurances Review—Staff Report.
}

In the context of the Extended Arrangement-Financing Assurances Review, the following document has been released:

- $\quad$ The staff report for the Extended Arrangement—Financing Assurances Review, prepared by a staff team of the IMF, briefly outlining performance under the Extended Arrangement, including compliance with end-December targets. The staff report was completed on February 24, 2010. The views expressed in the staff report are those of the staff team and do not necessarily reflect the views of the Executive Board of the IMF.

The policy of publication of staff reports and other documents allows for the deletion of market-sensitive information.

Copies of this report are available to the public from

International Monetary Fund • Publication Services

$70019^{\text {th }}$ Street, N.W. • Washington, D.C. 20431

Telephone: (202) 623-7430 • Telefax: (202) 623-7201

E-mail: publications@imf.org Internet: http://www.imf.org

\section{International Monetary Fund Washington, D.C.}




\title{
INTERNATIONAL MONETARY FUND
}

\section{SEYCHELLES}

\author{
Extended Arrangement-Financing Assurances Review \\ Prepared by the African Department \\ (In consultation with other Departments) \\ Approved by Johannes Mueller and Aasim Husain
}

February 24, 2010

1. The Executive Board approved a three year Extended Fund Facility with Seychelles effective December 23, 2009 in an amount equivalent to SDR 19.8 million (225 percent of quota), followed by the purchase of SDR 0.88 million (10 percent of quota). The second purchase of SDR 2.2 million (25 percent of quota) is contingent on observance of the endDecember 2009 quantitative performance criteria and completion of a financing assurances review. ${ }^{1}$ This report briefly outlines performance under the program, including compliance with the end-December targets, before addressing the issue of financing assurances.

\section{Program Performance}

2. Macroeconomic performance through end-2009 continued to be encouraging. Signs of recovery are apparent, on the heels of improving tourism activity. CPI inflation has been near zero since March and finished the year at minus 2.5 percent (end-period). Interest rates declined steadily and the 91-day T-bill stabilized at about 4.3 percent by end-year. Gross external reserves rose to 1.6 months of prospective imports, somewhat above target on building confidence in the rupee (Table 1).

\section{Prudent fiscal and monetary policies have been key to the strong macroeconomic} stabilization. Overall revenues over-performed projections in spite of the difficult environment and expenditures were within budget parameters, yielding a primary surplus of 14.4 percent. The stance of monetary policy remained broadly in line with the program and credit showed the signs of incipient recovery. The authorities have pursued active sterilization in the face of excess liquidity in the banking system as government has rapidly paid down domestic debt.

\footnotetext{
${ }^{1}$ Where the Fund is providing financial assistance to a member that has outstanding sovereign external payments arrears to private creditors, paragraph 11(c) (ii) of the Guidelines on Conditionality (http://www.imf.org/External/np/pdr/cond/2002/eng/guid/092302.htm) calls for the Executive Board to conduct a financing assurances review.
} 
4. All the quantitative performance criteria at end December 2009 were met with margins (Table 2). The structural benchmarks were also observed (Table 3). The 2010 budget was passed consistent with program understandings. The structural benchmarks for March 2010 are expected to be met, and the rest of the structural reform agenda continues to be implemented as scheduled.

\section{FinAnCING ASSURANCES REVIEW}

5. Strong progress continued to be made in implementing the public external debt restructuring. The exchange offer to holders of external bonds, notes, and certain commercial bank loans, successfully closed on January 14, 2010. The amortizing notes and commercial loans were tendered in their entirety, while 84 percent of the Eurobond debt was tendered, triggering the collective action clause. Tenders for the optional par bonds fell below the minimum threshold and the face value of the entire eligible debt (about US\$283 million, not including arrears and penalties) was restructured with a 50 percent face value reduction and long-term deferral of maturities. ${ }^{2}$ A goodwill cash payment in mid April of US\$17.6 million will be made in partial compensation for foregone interest. The new bonds attracted a rating of B- from Fitch ratings, with a positive outlook. With this exchange, about 70 percent of the public external debt stock at end-2008 eligible for restructuring has been restructured.

\section{Significant progress has also been achieved with remaining non-Paris Club} official bilaterals and external commercial banks. All bilateral creditors but one have either signed agreements or otherwise indicated their willingness to accept Paris Club terms. Agreements in principle have been reached with most commercial banks and discussions with remaining non-Paris Club bilaterals are advancing.

\section{As anticipated, the residual financing gaps for 2010 and the medium term,} identified at the time of program approval, have now been markedly reduced through the restructuring, and are expected to be entirely closed in the coming months as the remaining negotiations are concluded. The restructuring is consistent with program financing assumptions. Staff is of the view that the debt restructuring negotiations have proceeded in a manner consistent with the Fund's LIA policy. The authorities have dealt in good faith with all creditors and ensured inter-creditor equity. Accordingly, staff recommends completion of the financing assurances review.

\footnotetext{
${ }^{2}$ US\$169 million of long-term discount bonds were issued to creditors on February 11, 2010.
} 
Table 1. Seychelles: Selected Economic and Financial Indicators, 2007-09

\begin{tabular}{|c|c|c|c|c|}
\hline & \multirow[t]{2}{*}{2007} & \multirow[t]{2}{*}{2008} & \multicolumn{2}{|c|}{2009} \\
\hline & & & Prog. & Est. \\
\hline National income and prices ${ }^{1}$ & \multicolumn{4}{|c|}{ (Percentage change, unless otherwise indicated) } \\
\hline Nominal GDP (millions of Seychelles rupees) & 6,877 & 8,756 & 10,402 & 10,322 \\
\hline Real GDP & 9.7 & -0.9 & -7.6 & -7.6 \\
\hline CPI (annual average) & 5.3 & 37.0 & 32.9 & 31.8 \\
\hline CPI (end-of-period) & 16.8 & 63.3 & 1.9 & -2.5 \\
\hline GDP deflator average & 11.4 & 28.4 & 28.5 & 27.5 \\
\hline Money and credit & \multicolumn{4}{|c|}{ (Percentage change, unless otherwise indicated) } \\
\hline Net claims on private sector & 9.3 & 58.4 & -12.1 & -16.9 \\
\hline Broad money $(\mathrm{M} 3(\mathrm{p}))^{2}$ & -7.6 & 27.2 & -0.7 & 7.5 \\
\hline Reserve money & -23.1 & 0.6 & 32.2 & 15.7 \\
\hline Velocity (GDP/M3) & 1.5 & 1.5 & 1.8 & 1.6 \\
\hline Money multiplier (M3/reserve money) & 4.2 & 5.3 & 4.0 & 4.9 \\
\hline Savings-Investment balance & \multicolumn{4}{|c|}{ (In percent of GDP) } \\
\hline External savings & 20.8 & 44.7 & 22.6 & 22.5 \\
\hline Gross national savings & 8.0 & -12.7 & 6.8 & 7.0 \\
\hline Of which: government savings & -4.4 & 4.2 & 2.8 & 4.7 \\
\hline Gross investment & 28.8 & 32.1 & 29.4 & 29.5 \\
\hline Of which: government investment & 5.5 & 2.1 & 5.3 & 5.6 \\
\hline \multicolumn{5}{|l|}{ Government budget } \\
\hline Total revenue, excluding grants & 32.0 & 32.8 & 35.6 & 36.7 \\
\hline Expenditure and net lending & 40.9 & 39.8 & 35.1 & 34.7 \\
\hline Current expenditure & 36.3 & 28.6 & 32.8 & 32.1 \\
\hline Capital expenditure and net lending ${ }^{3}$ & 4.6 & 11.2 & 2.3 & 2.6 \\
\hline Overall balance, including grants & -8.7 & -3.3 & 2.8 & 4.4 \\
\hline Primary balance & -2.0 & 3.8 & 13.3 & 14.4 \\
\hline Total public debt ${ }^{4,5}$ & 129.8 & 135.7 & 140.1 & 128.0 \\
\hline Domestic & 65.8 & 52.3 & 41.6 & 37.4 \\
\hline External 4,5 & 63.9 & 83.3 & 98.5 & 90.6 \\
\hline External sector & \multicolumn{4}{|c|}{ (In percent of GDP, unless otherwise indicated) } \\
\hline Current account balance including official transfers & -20.8 & -44.7 & -22.6 & -22.5 \\
\hline Total stock of arrears (millions of U.S. dollars) ${ }^{4,5}$ & 160 & 322 & 239 & 209 \\
\hline Total external debt outstanding (millions of U.S. dollars) ${ }^{4,5}$ & 710 & 768 & 755 & 690 \\
\hline (in percent of GDP) ${ }^{4,5}$ & 69.2 & 83.3 & 98.5 & 90.6 \\
\hline Terms of trade (= - deterioration) & -1.2 & 0.7 & -2.1 & -2.1 \\
\hline Real effective exchange rate (end-of-period, percent changè) ${ }^{6}$ & -25.4 & -18.4 & 13.0 & 13.0 \\
\hline Gross official reserves (end of year, millions of US dollars) & 10 & 51 & 153 & 169 \\
\hline In months of imports, c.i.f. & 0.1 & 0.6 & 1.5 & 1.6 \\
\hline \multicolumn{5}{|l|}{ Exchange rate } \\
\hline Seychelles rupees per US $\$ 1$ (end of period) & 8.0 & 16.6 & 10.6 & 11.3 \\
\hline Seychelles rupees per US $\$ 1$ (period average) & 6.7 & 9.5 & 14.1 & 13.7 \\
\hline
\end{tabular}

Sources: Central Bank of Seychelles; Ministry of Finance; and IMF staff estimates and projections.

${ }^{1}$ Historic GDP data have been revised upwards in April 2009.

${ }^{2}$ In 2007 and earlier, includes domestic currency balances earmarked for pending import requests ("pipeline").

${ }^{3}$ In 2010 includes contingency spending of 1.1 percent of GDP

${ }^{4}$ Assumes April 2009 Paris Club agreement is implemented; does not include any further restructuring of external debt.

${ }^{5}$ Includes arrears and the external debt of the central bank.

6 REER is change from Dec. 2008 through Sep. 2009. 
Table 2. Seychelles: Quantitative Performance Criteria Under the EFF, December 2009 - December 2010 (Millions of Seychelles rupees; end-of-period)

\begin{tabular}{|c|c|c|c|c|c|c|c|}
\hline & \multirow{2}{*}{\multicolumn{3}{|c|}{2009}} & \multicolumn{4}{|c|}{2010} \\
\hline & & & & \multirow{2}{*}{ March } & \multirow{2}{*}{$\begin{array}{l}\text { June } \\
\text { Program }\end{array}$} & \multirow{2}{*}{$\begin{array}{l}\text { September } \\
\text { Program }\end{array}$} & \multirow{2}{*}{$\begin{array}{l}\text { December } \\
\text { Program }\end{array}$} \\
\hline & Program & Adusted & Actual & & & & \\
\hline \multicolumn{8}{|l|}{ Performance criteria } \\
\hline Net international reserves of the CBS, millions of U.S. dollars (floor) ${ }^{1}$ & 130 & 138 & 153 & 133 & 128 & 142 & 168 \\
\hline Reserve money (ceiling) & 1,480 & $\ldots$ & 1,296 & 1,537 & 1,592 & 1,676 & 1,753 \\
\hline Primary balance of the consolidated government (cumulative floor) ${ }^{2,3}$ & 1,375 & $\cdots$ & 1,491 & 261 & 437 & 659 & 761 \\
\hline $\begin{array}{l}\text { The contracting or guaranteeing of new external debt by the public sector } \\
\text { (Millions of U.S. dollars; cumulative ceiling) }\end{array}$ & 39 & $\cdots$ & 30 & 2 & 3 & 13 & 37 \\
\hline $\begin{array}{l}\text { The contracting or guaranteeing of new short-term external debt by the public s } \\
\text { (Millions of U.S. dollars; cumulative ceiling) }{ }^{2}\end{array}$ & 0.0 & $\cdots$ & 0.0 & 0.0 & 0.0 & 0.0 & 0.0 \\
\hline The accumulation of external payments arrears by the public sector (ceiling) ${ }^{3}$ & 0.0 & $\cdots$ & 0.0 & 0.0 & 0.0 & 0.0 & 0.0 \\
\hline The accumulation of domestic payment arrears by the public sector (ceiling) & 0.0 & $\ldots$ & 0.0 & 0.0 & 0.0 & 0.0 & 0.0 \\
\hline \multicolumn{8}{|l|}{ Memorandum items: } \\
\hline External non project financing (millions of U.S. dollars; cumulative) ${ }^{2}$ & -17.2 & $\ldots$ & -9.4 & 1.7 & 1.8 & 9.0 & 31.8 \\
\hline Program financing support & 19.6 & $\ldots$ & 11.2 & 0.0 & 0.0 & 0.0 & 19.6 \\
\hline Cash payments on foreign debt service & 48.1 & $\ldots$ & 32.1 & 1.8 & 5.8 & 6.9 & 9.2 \\
\hline External budget grants & 11.3 & $\cdots$ & 11.5 & 3.5 & 7.6 & 15.9 & 21.4 \\
\hline \multicolumn{8}{|l|}{ Program accounting exchange rates } \\
\hline SR/US\$ (end-of-quarter) & 11.00 & $\ldots$ & 11.25 & 11.00 & 11.00 & 11.00 & 11.00 \\
\hline US $\$$ /Euro (end-of-quarter) & 1.48 & $\ldots$ & 1.43 & 1.48 & 1.48 & 1.48 & 1.48 \\
\hline US\$/UK pound (end-of-quarter) & 1.65 & $\ldots$ & 1.62 & 1.65 & 1.65 & 1.65 & 1.65 \\
\hline US\$/SDR (end-of-quarter) & 1.59 & $\ldots$ & 1.57 & 1.59 & 1.59 & 1.59 & 1.59 \\
\hline
\end{tabular}

Sources: Seychelles authorities, and IMF staff estimates and projections.

1 The floor will be adjusted downwards (upwards) for any shortfall (excess) in external nonproject financial support from that assumed in the program.

2 Cumulative flows from the beginning of the calendar year.

${ }^{3}$ The non-accumulation of new external payment arrears constitutes a continuous performance criterion. Excludes arrears for which a rescheduling agreement is sought. 
5

Table 3. Seychelles: Structural Benchmarks for 2009-10

\begin{tabular}{|c|c|c|c|}
\hline Measure & Target date & Macroeconomic rationale & Status \\
\hline $\begin{array}{l}\text { Complete CBS procedures } \\
\text { manual (MEFP, } \mathbb{\uparrow 4 6 ) .}\end{array}$ & $\begin{array}{l}\text { End- } \\
\text { December } 2009\end{array}$ & $\begin{array}{l}\text { To support improved } \\
\text { efficiency and transparency } \\
\text { in monetary policy. }\end{array}$ & Met. \\
\hline $\begin{array}{l}\text { CBS to publish commercial bank } \\
\text { supervision report (MEFP, } \uparrow 46) \text {. }\end{array}$ & $\begin{array}{l}\text { End- } \\
\text { December } 2009\end{array}$ & $\begin{array}{l}\text { To promote competition and } \\
\text { transparency in the banking } \\
\text { system. }\end{array}$ & Met. \\
\hline $\begin{array}{l}\text { Amend the Business Tax Act in } \\
\text { line with the tax reform strategy } \\
\text { (MEFP, }\{22) \text {. }\end{array}$ & $\begin{array}{l}\text { End- } \\
\text { December } 2009\end{array}$ & $\begin{array}{l}\text { To broaden the tax base, } \\
\text { modernize tax policy, and } \\
\text { remove distortions. }\end{array}$ & Met. \\
\hline $\begin{array}{l}\text { Cabinet approval of customs } \\
\text { reform strategy and } \\
\text { implementation plan (MEFP, } \\
\text { (23). }\end{array}$ & End-March 2010 & $\begin{array}{l}\text { To transform customs into a } \\
\text { modern and efficient entity. }\end{array}$ & \\
\hline $\begin{array}{l}\text { Publish general government } \\
\text { fiscal statistics (MEFP, ๆ29). }\end{array}$ & End-April 2010 & $\begin{array}{l}\text { To enhance transparency } \\
\text { and coverage of public } \\
\text { finance. }\end{array}$ & \\
\hline $\begin{array}{l}\text { Submit to National Assembly a } \\
\text { new customs management act } \\
\text { (MEFP, }\{23 \text { ). }\end{array}$ & End-June 2010 & $\begin{array}{l}\text { To institutionalize best } \\
\text { international practice and a } \\
\text { better business climate. }\end{array}$ & \\
\hline $\begin{array}{l}\text { Introduce Personal Income Tax } \\
\text { (MEFP, ๆ22). }\end{array}$ & July 1,2010 & $\begin{array}{l}\text { To broader the tax base and } \\
\text { provide for more equitable } \\
\text { taxation. }\end{array}$ & \\
\hline $\begin{array}{l}\text { Introduce budget submissions } \\
\text { protocols and procedures } \\
\text { (MEFP, ๆ28). }\end{array}$ & End-July 2010 & $\begin{array}{l}\text { To strengthen budget } \\
\text { preparation. }\end{array}$ & \\
\hline $\begin{array}{l}\text { Adopt a new chart of accounts } \\
\text { for the } 2011 \text { budget } \\
\text { (MEFP, } \text { (29). }\end{array}$ & $\begin{array}{l}\text { End- } \\
\text { November } 2010\end{array}$ & $\begin{array}{l}\text { To ensure proper } \\
\text { classification and increase } \\
\text { efficiency of the budget as a } \\
\text { policy tool. }\end{array}$ & \\
\hline $\begin{array}{l}\text { Submit to National Assembly a } \\
\text { bill creating a national clearing } \\
\text { house and settlement system } \\
\text { (MEFP, } \mid 44 \text { ). }\end{array}$ & $\begin{array}{l}\text { End- } \\
\text { December } 2010\end{array}$ & $\begin{array}{l}\text { To introduce necessary } \\
\text { financial infrastructure for } \\
\text { improved efficiency and } \\
\text { reduced risks. }\end{array}$ & \\
\hline
\end{tabular}

